\title{
Green building literacy: a framework for advancing green building education
}

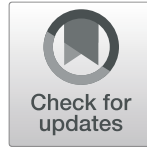

Laura B. Cole(i)

\begin{abstract}
Background: Despite the increasing square footage of green buildings worldwide, green building expertise remains largely in the domain of building industry professionals. However, the performance of and advocacy for green buildings would benefit from a green building literate general public. Green building education is an expanding frontier for STEM education and can create opportunities to integrate science and environmental literacies into the study of everyday environments. Few resources exist, however, to help STEM educators incorporate green building themes into the science classroom. The work here developed educational tools for connecting green buildings and science education through a multi-step process. An interdisciplinary literature review yielded a series of frameworks that were improved through two focus groups with science and environmental educators and built environment professionals.
\end{abstract}

Results: The result of this process is a toolbox of conceptual frameworks for educators interested in using a systemsbased approach to teach about green buildings as sites for complex interactions between human activity and Earth systems. The work here first leverages the broad definition of environmental literacy (knowledge, skills, affect, and behavior) to advance a working definition for "green building literacy." Next, major domains of green building knowledge are developed and linked to the Next Generation Science Standards.

Conclusions: Green building literacy has been an ill-defined term and green building themes have not been rigorously connected to science and environmental education. The work here provides a foundation for promoting green building literacy through K-12 STEM education. The educational tools developed through this process can be used as a starting point for lesson planning to catalyze green building education in a variety of formal and informal settings.

Keywords: Green building literacy, Green building education, Environmental literacy, Science literacy, Curriculum design, Next generation science standards

\section{Introduction}

The overarching goals of building "green" are to reduce the social and environmental impacts of the built environment while improving the quality of life for occupants within buildings. In the USA, residential and commercial buildings consume $40 \%$ of total energy consumption and $75 \%$ of all electricity produced (U.S. Energy Information Administration, 2012). The average American family uses 300 gal of water a day, where $70 \%$ of that water use occurs indoors (U.S. Environmental Protection Agency, n.d.). The contemporary green building movement promotes buildings that lessen these environmental impacts

Correspondence: colelb@missouri.edu University of Missouri, Columbia, USA through better building construction (e.g., less construction waste), building operation and maintenance (e.g., water and energy conservation and better indoor air quality), and lifecycle considerations (e.g., recycling and deconstruction at the end of a building's life) (International Living Future Institute, n.d.; USGBC, n.d.). However, the problem remains that few people outside the building industry understand the myriad benefits of building green (Cole, 2013).

Public green building education matters for a variety of reasons. To begin, people are life-long building consumers and occupants within buildings can be crucial agents of change for resource conservation measures such as energy efficiency and material recycling (e.g., Gill, Tierney, Pegg, \& Allan, 2010; Wu, DiGiacomo, 
Lenkic, Wong, \& Kingstone, 2016). A building's design and resultant ecological performance may depend on occupant behaviors such as minimizing space heaters under the desk, turning off lights, and knowing when to close or open a window. Additionally, for residential structures, many people will at some point in their lives own and maintain, or rent and seek to improve, their own homes. Adults will increasingly need to engage with tax incentives for green home features and learn how to do home renovations or consult professionals for upgrades like better insulation, water efficient fixtures, or solar panel installation. Gaining expertise in green building strategies is therefore comparable to other basic skills in the home economy such as cooking nutritious meals or balancing finances. Finally, energy and atmosphere issues dominate the U.S. Labor Industry's working definition of a green workforce (SEED Center, n.d.). Green buildings can make significant contributions to solving energy and atmosphere challenges and will require an increasingly knowledgeable workforce to design, build, and maintain. These foundations for green building literacy can begin in the K-12 classroom.

Green building literacy (GBL) is the term used here to describe the hoped-for outcome of green building education [which falls within the larger movement for public "built environment education" (e.g., Portillo \& Rey-Barreau, 1995)]. To craft green building education programs, a framework is needed to understand prospects for GBL. The conceptual framework for GBL presented below builds off the four core themes integrated into frameworks for environmental literacy over time. Despite much variation in terminology, these four dimensions are knowledge, skills, affect, and behavior (terms used in the McBride, Brewer, Berkowitz, \& Borrie, 2013 overview of environmental literacy frameworks). To date, little effort has been made to stitch together these domains with the topic of green building design. The current author presented the "Major features of green building literacy" in previous reporting as a theoretical background for empirical work in green schools (Cole, 2015). This work utilized the Marcinkowski (2010) matrix for "Major Features of Environmental Literacy," a framework chosen for its clear distillation of themes and for its practical emphasis on identifying issues and solving problems. Previous publications on GBL, however, have not clearly identified the multiple dimensions of GBL from a theoretical point of view or aligned outcomes to STEM education. Doing so can inform a range of practices (from curriculum to building design) for various age groups given the broad nature of the foundational categories for environmental literacy presented by McBride et al. (2013).

Previous work on GBL was additionally conducted through a research project entitled "Green Building Technology Education," funded by the National Science
Council in Taiwan, which focused on green building education at the college level (Shiao, Lin, \& Sung, 2013). Scholars in this group used the Roth (1992) work on environmental literacy to build curriculum and develop an evaluation tool for GBL (Jan, Lin, Shiao, Wei, Huang, \& Sung, 2012). Their study involved a curricular intervention in an undergraduate general education course with pre- and post-course surveys measuring GBL, where they found significant increases in knowledge, attitudes, and behaviors from pre- to post-course (Shiao et al., 2013). They also identified a gap between positive attitudes and actual behaviors related to green buildings, which they attributed to the lack of green building skills (Jan et al., 2012). The work here expands the scholarship from Taiwan in several key ways. First, the "Major features of green building literacy" framework presented here offers a broader spectrum of pedagogical approaches to green building education compared to work by Shiao et al. (2013). The framework presented here incorporates multiple dimensions of green building knowledge (factual, conceptual, and procedural), where previous work has not considered various knowledge domains (i.e., those inspired by Bloom, Engelhart, Furst, Hill, \& Krathwohl, 1956) and how these different kinds of knowledge relate to green building education. Second, this paper outlines a larger array of green building learning content. The scholarship in Taiwan was based on the Taiwan Green Building Label rating system (Tawain Green Building Label, n.d.), which was developed specifically for tropical climates. This paper integrates international green building rating systems to offer 14 green building knowledge categories. This paper additionally provides educators with an integrative framework that places green buildings within infrastructural, ecological, and social contexts in alignment with the Next Generation Science Standards (NGSS) (NGSS Lead States, 2013) (Additional file 1). In doing so, the hope is that educators can increasingly teach about green buildings as dynamically interconnected with surrounding social and physical contexts while meeting stringent standards for science education. Finally, work in Taiwan was crafted specifically for the green building education of college students. The work here seeks to inform K-12 educators and curriculum developers who aspire to increase GBL for youth.

Improving the definition of GBL has implications for theories of teaching and learning. First, crafting a framework for GBL promotes exciting future directions for educators interested in experiential and place-based education (Barr, Dunbar, \& Schiller, 2012). Learners can, of course, engage with green buildings themes by reading and watching educational media. However, green building knowledge can also be gained through hands-on lessons in the home, school building, public buildings, and 
beyond in community infrastructure (Cole, McPhearson, Herzog, \& Kudryavtsev, 2017). As Sobel (2004) defines it, place-based education is "the process of using the local community and environment as a starting point to teach concepts in language arts, mathematics, social studies, science and other subjects across the curriculum" (p. 6). The study of buildings within infrastructure and ecology aligns well with Sobel's vision of treating the surrounding community as an extension of the classroom and complement to textbook learning (Sobel, 2004).

The sections to follow address each the practical and theoretical aspects of GBL. First, GBL is theoretically positioned within the larger discourses of environmental literacy and science literacy. Second, the "Major features of green building literacy" are presented as a set of frameworks that can be used by educators and curriculum developers to integrate green building themes into STEM education.

\section{Theorizing green building literacy}

While green building themes can be viewed through numerous disciplinary lenses, the current work examines green building design as nested within the broader topics of environmental literacy and science literacy. A green building literate citizen will benefit from foundational knowledge from environmental/sustainability education and science education to understand both the what and why of green building design and ultimately how to engage in transformative green buildings practices.

Just as the term "environmental literacy" has been the subject of much debate (e.g., McBride et al., 2013), the term "science literacy" has been similarly elusive to define (e.g., DeBoer, 2000; Roberts, 2007). Both types of literacy, however, share the challenge of blurred boundaries between the physical sciences and socio-cultural themes. Environmental literacy is conceptualized as a combination of social and ecological forces, or an overlap of ecological literacy with civics literacy (Berkowitz, Ford, \& Brewer, 2005; McBride et al., 2013), that attempts to thread together the complex relationships between human activity and ecosystem health. Likewise, for science literacy, the needs to place science within applied contexts necessitates some level of systems thinking that engages disciplines outside the physical sciences, which stands in contrast to a formulation of science literacy that stays "within science" (a distinction well-articulated by the Roberts, 2007 notion of Visions I and II for science/scientific literacy). Science standards for K-12 education, such as the NGSS, additionally include guidelines for teaching at the intersections of Earth systems and human activity (NGSS Lead States, 2013). Architectural environments, commonly infused with scientific advancements, are potent and very tangible manifestations of how humans interface with ecology. Green building design is thus uniquely positioned at the intersection of a variety of socio-cultural, technological, and ecological themes. However, educators need not expand to dimensions beyond science to engage in green building education. Green building design is fundamentally based on scientific concepts and can be viewed through a purely scientific lens. While the topic of green buildings is malleable to a variety of conceptualizations within the broader ideas of science literacy and environmental literacy, the frameworks introduced here were created with a mind toward the potential for interdisciplinarity.

Adding the notion of green building literacy (GBL) to the crowded field of "literacies" is not an exercise to take lightly. A more in-depth justification for why literacy is the appropriate terminology for advancing green building education is warranted. Stables and Bishop (2001) warn that "the term 'literacy' has been degraded as a result of its indiscriminate application" (p. 90). They argue that the application of the term to a variety of domains (e.g., environmental, technological, and computer literacies) has not been sufficiently grounded in the linguistic and literary origins of the notion of "literacy." In their argument for a "strong conception of environmental literacy," they advocate for an expansive conceptualization of the term "environmental literacy," where literacy is not restricted to textual literacy, but understood as a broader engagement with the biophysical environment. Their work draws on work by de Saussure (1966) on semiology, the study of both linguistic and non-linguistic communication via the use of "signs" that are open to a variety of interpretations. Stables and Bishop (2001) argue for an understanding of environmental literacy as a semiotic engagement with our surrounding environment where the biophysical environment can be thought of a text that we both "read" (understand) and "write" (act on). In this view, the environment is not only an ecological reality but also open to a variety of scientific, historical, and esthetic interpretations (Stables \& Bishop, 2001, p. 93). McBride et al. (2013) also addressed the need to understand the term "literacy" beyond textual literacy by stating that "... expectations for a literate citizenry have been extended to include the ability to understand, make informed decisions, and act with respect to complex topics and issues facing society today" (McBride et al., 2013, p. 2).

Conceptualizations of GBL can meet the Stables and Bishop (2001) criteria of being "strong." Like the biophysical environment, buildings too can be read and written. This is a particularly interesting question in school buildings where the building can act as one stream of messaging among many others (Cole, 2018; Higgs \& McMillan, 2006; Shapiro, 2015). Aligning with Stables and Bishop's (2001) conceptualization, buildings 
may fit the same role as the biophysical environment, offering a palette of signs open to interpretation by building occupants and therefore providing a unique medium for environmental education. Buildings, perhaps even more than natural settings, are open to a multitude of interpretations with diverse layers-socio-cultural, biophysical, technical, historic, etc.-to comprehend. The term "green building literacy," as used here, thus shares the strong conception of environmental literacy envisioned by Stables and Bishop (2001) as a fluid outcome rooted in time and context.

Like textual literacy and the Stables (1998) model for environmental literacy, GBL can also be understood as variously functional, cultural, and critical. The framework for GBL presented here lays the groundwork for functional GBL (the basic ability to "read" a green building) by outlining the diverse domains of green building knowledge. These knowledge domains are not simply about buildings as objects, however; the framework conceives green buildings as cultural artifacts that intersect with themes of economy, social justice, and esthetics. Green building education, therefore, can integrate cultural GBL (understanding the significance of green building practices) by encouraging learners to decode the kinds of socio-cultural messages that buildings impart. Better yet, green building education can foster critical GBL, where learners critically engage with green buildings to question the cultural, social, and political forces that both shape-and are shaped by-buildings. Stables (1998) argues that functional and cultural literacy are required for critical literacy, and effective environmental action requires critical environmental literacy. This may be true in the arena of green building design, where a basic understanding of green buildings is the foundation for active and effective participation in the green building movement.

\section{Methods: green building literacy framework development}

To develop this provisional framework for green building literacy (GBL), the guiding question was: what are the core qualities of a green building literate citizen? This study used a simplified and qualitative Delphi technique (e.g., Murry \& Hammons, 1995) to create, present, and revise the frameworks presented here. First, an interdisciplinary review of literature across environmental education and built environment studies yielded a series of diagrams and tables that convey the major tenants of GBL. Second, these intellectual resources were shared with an expert panel of practitioners and scholars in both education and architecture in two web-based focus group settings. Finally, insights from the focus groups were used to improve the frameworks including the creation of additional tools to connect green building knowledge domains with current standards for science education.

\section{Interdisciplinary literature review}

The foundation of the framework begins with the core dimensions of environmental literacy (knowledge, skills, affect, and behaviors) (McBride et al., 2013) which are then adapted to the topic of green building design (Table 1). Frameworks from the realms of education and architectural studies are then used to build each of these dimensions outward. First, the domains of knowledge and skills in this framework are informed by a revised version of Bloom's Taxonomy (Krathwohl, 2002). The dimension of "skills" is here identified as "procedural knowledge" and combined with the other dimensions of knowledge to illustrate a continuum of knowledge from understanding (factual and conceptual knowledge) to action (procedural knowledge). Next, frameworks for green building design are used to establish a series of categories for green building knowledge (Table 2). The section on "Green building knowledge and skills" additionally includes a review of key crossover themes between green buildings and the NGSS to identify the strong potential for curricular integration. Finally, the themes of affect and behavior within green building education are discussed. The result is a provisional framework for GBL that can be used to both create and evaluate green building curriculum for the K-12 classroom.

\section{Focus groups}

Following ethics approval and consent of the participants, the first iterations of Tables 1 and 2 were shared with professionals in two focus group settings. One focus group was comprised of professionals in the realm of environmental and science education $(n=5)$, hereafter called the "Educator Focus Group." The second focus group engaged built environment (BE) professionals across interior design and architecture who all had experience in the area of green building design $(n=7)$, hereafter called the "BE Focus Group." Both groups were comprised of a mix of practitioners and academic scholars. A convenience sampling technique followed by a snowball sampling technique were both used to identify and recruit focus group participants. The researcher invited contacts in her own network and requested that those contacts help to identify other professionals who could offer valuable perspective on the topic of green building education. This sampling resulted in a group of experts who are all in North America and mostly located in regions across the USA. The Educator focus group included one West coast educator, a Midwest scholar, a Midwest sustainability coordinator originally from India, an East coast educator, and an East coast non-profit manager. The BE focus group included one scholar from 
Table 1 Major features of green building literacy

\begin{tabular}{|c|c|c|}
\hline \multicolumn{2}{|l|}{ Dimension } & \multirow{2}{*}{$\begin{array}{l}\text { Description } \\
\text { Knowledge of the various components of green building design (e.g., wind turbines, } \\
\text { recycled content materials, or dual-flush toilets) }\end{array}$} \\
\hline $\begin{array}{l}\text { Green building } \\
\text { knowledge and skills }\end{array}$ & Factual knowledge & \\
\hline & Conceptual knowledge & $\begin{array}{l}\text { Knowledge of the relationships between elements within green buildings (e.g., how } \\
\text { operating windows affects cooling systems) and between buildings and other built } \\
\text { and natural systems (e.g., the dangers of glass facades for birds) }\end{array}$ \\
\hline & Procedural knowledge (skills) & $\begin{array}{l}\text { Skills such as making design choices (e.g., picking eco-friendly furniture), analyzing the } \\
\text { performance of the design (e.g., monitoring solar panels), or properly operating green } \\
\text { buildings (e.g., knowing how to operate the window shades to reduce solar gain in } \\
\text { the afternoon sun) }\end{array}$ \\
\hline \multirow[t]{2}{*}{$\begin{array}{l}\text { Affective dispositions } \\
\text { and green buildings }\end{array}$} & $\begin{array}{l}\text { Dispositions that contribute to } \\
\text { green building practices }\end{array}$ & $\begin{array}{l}\text { Baseline attitudes and values that may impact the acquisition of green building } \\
\text { knowledge and the adoption of green building behaviors (e.g., environmental } \\
\text { sensitivity, personal responsibility, self-efficacy, locus of control, behavioral willingness) }\end{array}$ \\
\hline & $\begin{array}{l}\text { Dispositions that result from } \\
\text { green building practices }\end{array}$ & $\begin{array}{l}\text { Attitudes and values that may result from sustained engagement with a green building } \\
\text { (e.g., environmental sensitivity and place attachment) }\end{array}$ \\
\hline \multirow[t]{2}{*}{$\begin{array}{l}\text { Behaviors and green } \\
\text { buildings }\end{array}$} & $\begin{array}{l}\text { Advancing green building } \\
\text { practices }\end{array}$ & $\begin{array}{l}\text { Seeking knowledge about or advocating for green building practices individually or } \\
\text { collectively and at various levels (personal, family, community, governmental, etc.) (e.g., } \\
\text { researching green buildings, encouraging parents to experiment at home with green } \\
\text { building features, or working with peers to contact policy makers) }\end{array}$ \\
\hline & $\begin{array}{l}\text { Behaviors within green } \\
\text { buildings }\end{array}$ & $\begin{array}{l}\text { Participating in environmentally responsible behaviors in and around green buildings } \\
\text { (e.g., recycling, taking the stairs instead of the elevator, or turning off lights) }\end{array}$ \\
\hline
\end{tabular}

the Mountain West, an architect from the Midwest, a scholar/architect from Turkey who resides in the Midwest, two scholars from the Southern US, a scholar from the East coast, and a scholar from Canada. Both focus group sessions were 60-min long, conducted online, and included a 10-min presentation of the frameworks by the researcher followed by a structured conversation that focused on obtaining expert feedback. Consensus was not derived through successive quantitative surveys, as is common in Delphi panels. Instead, points of contention were discussed as they arose in the focus group setting and the researcher ensured that all points of view were registered before changing topics.

The transcripts from each focus group were imported into qualitative analysis software and analyzed by the researcher in a two-step coding process that first identified topics of discussion through open coding then a second examination of the data to coalesce topics into broader themes. The final Tables 1 and 2 frameworks presented here are the result of integrating feedback across the professional and disciplinary perspectives. The "Major features of green building literacy" are presented in the next section followed by a summary of the three major themes that arose in the focus group settings in reaction to the frameworks.

\section{Major features of green building literacy Green building knowledge and skills}

What kind of knowledge might a green building literate citizen possess? The sections below unpack the multiple dimensions of green building knowledge. The Taxonomy table from the Krathwohl (2002) adaptation to Bloom's Taxonomy (Bloom et al., 1956) is a framework commonly employed by environmental education scholars (e.g., Iozzi, Laveault, \& Marcinkowski, 1990; Monroe, Andrews, \& Biedenweg, 2008). The framework posits a six-step cognitive process dimension (remember, understand, apply, analyze, evaluate, create) and draws it across four different kinds of knowledge (factual, conceptual, procedural, metacognitive). Green building lesson plans can incorporate the six cognitive processes. Further, green building knowledge can fall along this spectrum of knowledge types. The sections below take the first three knowledge types as a starting point to define a typology for green building knowledge.

\section{Factual green building knowledge}

The factual information that underlies green building design is vast. Green buildings intersect with a wide set of environmental issues (materials, energy, water, etc.). However, numerous existing frameworks are used to organize and measure what it means for a building to be green. These tools can be used to organize content areas for green building lesson planning. Table 2 collects themes in one place, where categories are derived from previous GBL frameworks (Shiao et al., 2013), green building rating systems (CHPS, 2014; International Living Future Institute, n.d.; USGBC, 2008), and green school award programs (Pastorius \& Marcinkowski, 2013) and focus group feedback. Further inspiration was drawn from the McLennan (2004) compendium on philosophies of sustainable design. The five key categories most commonly found across green building rating systems include sustainable sites, location and transportation, energy and atmosphere, water, materials, and indoor air quality. The category of "shape of building" has been added to this framework given the importance of building orientation on the site 
Table 2 Green building knowledge categories

\begin{tabular}{|c|c|c|}
\hline Category & Sample themes (factual and conceptual knowledge) & Sample skills (procedural knowledge) \\
\hline Sustainable sites & $\begin{array}{l}\text { Stormwater management; effects of the building on light } \\
\text { pollution; heat island effect }\end{array}$ & $\begin{array}{l}\text { - Measure water quality on building site } \\
\text { - Install water-saving landscape features (e.g., rain barrels) }\end{array}$ \\
\hline Location and transportation & $\begin{array}{l}\text { Sensitive land protection; neighborhood density; green } \\
\text { transportation }\end{array}$ & - Calculate effects of population density on biodiversity \\
\hline Shape of building & $\begin{array}{l}\text { Size and compactness of building (e.g., occupants per } \\
\text { square foot/meter); door and window locations; } \\
\text { orientation of the building on the site relative to sun } \\
\text { and wind }\end{array}$ & $\begin{array}{l}\text { - Measure and compare solar gain through windows that } \\
\text { face various cardinal directions }\end{array}$ \\
\hline Energy and atmosphere & $\begin{array}{l}\text { Energy reduction; energy efficiency; the carbon footprint } \\
\text { that results from the building construction and operations }\end{array}$ & $\begin{array}{l}\text { - Measure kilowatt hours and determine energy-saving } \\
\text { solutions } \\
\text { - Monitor solar panel performance }\end{array}$ \\
\hline Water & $\begin{array}{l}\text { Conservation of water through building fixtures such } \\
\text { as toilets and sinks; water issues in the landscape such } \\
\text { as rainwater harvesting and drought-tolerant plantings }\end{array}$ & $\begin{array}{l}\text { - Use water-saving landscape features } \\
\text { - Select water-saving plumbing fixtures }\end{array}$ \\
\hline $\begin{array}{l}\text { Materials and waste } \\
\text { management }\end{array}$ & $\begin{array}{l}\text { Building material considerations such as: recycled } \\
\text { content, recyclable, rapidly renewable, sustainable } \\
\text { wood products, local materials, re-purposed materials; } \\
\text { overall reduction in material use }\end{array}$ & $\begin{array}{l}\text { - Build furniture out of salvaged materials } \\
\text { - Research the social, ecological, and economic impacts } \\
\text { of a building product like carpet, wood, or stone }\end{array}$ \\
\hline Indoor environmental quality & $\begin{array}{l}\text { Indoor air quality; moisture and temperature control; } \\
\text { connect occupants to nature via daylight, views, and } \\
\text { biophilic design }\end{array}$ & $\begin{array}{l}\text { - Assess environmental toxins such as mold and radon } \\
\text { - Select furniture that promotes healthier air quality } \\
\text { - Study psychological impact of daylight }\end{array}$ \\
\hline Social justice & $\begin{array}{l}\text { Affordability; accessibility; positive or negative impacts } \\
\text { to communities locally and globally due to green } \\
\text { building design choices }\end{array}$ & $\begin{array}{l}\text { - Advocate for equitable green building solutions } \\
\text { - Volunteer construction skills in communities of need }\end{array}$ \\
\hline Beauty and inspiration & $\begin{array}{l}\text { Designs that "elevate our spirits and inspire us to be } \\
\text { better than we currently are" (International Living } \\
\text { Future Institute, n.d.); show innovation compared to } \\
\text { past practices }\end{array}$ & $\begin{array}{l}\text { - Paint a mural that celebrates the history of the building } \\
\text { site } \\
\text { - Compare old and new building practices }\end{array}$ \\
\hline Economics & $\begin{array}{l}\text { Cost-saving features; long-term budgeting; trade-offs } \\
\text { between cost and performance }\end{array}$ & $\begin{array}{l}\text { - Calculate energy savings } \\
\text { - Compare costs of green building materials }\end{array}$ \\
\hline Life cycle assessment & $\begin{array}{l}\text { Ecological impacts across the life of building materials } \\
\text { from creation to use to end-of-life; Embodied energy } \\
\text { in furniture and building materials }\end{array}$ & $\begin{array}{l}\text { - Follow a building product from "cradle to grave" or } \\
\text { "cradle to cradle" (Braungart et al., 2007) }\end{array}$ \\
\hline Operations and metrics & $\begin{array}{l}\text { Green cleaning; occupant education and training; } \\
\text { building information modeling (BIM); performance } \\
\text { monitoring }\end{array}$ & $\begin{array}{l}\text { - Contrast and compare environmental effects of various } \\
\text { cleaning products on air and water quality } \\
\text { - Monitor performance of HVAC system }\end{array}$ \\
\hline Local and healthy food & $\begin{array}{l}\text { The built infrastructure for growing and consuming } \\
\text { food that is healthy for people and the environment } \\
\text { (e.g., greenhouses, edible landscapes, etc.) }\end{array}$ & $\begin{array}{l}\text { - Design and properly orient a greenhouse } \\
\text { - Design and build a vegetable garden for wheelchair } \\
\text { accessibility }\end{array}$ \\
\hline Policy & $\begin{array}{l}\text { The relationship between green buildings and the } \\
\text { political context, including local/regional/national } \\
\text { policies, codes, guidelines, strategic plans, etc. that } \\
\text { affect green building practices }\end{array}$ & $\begin{array}{l}\text { - Examine local residential building codes and identify } \\
\text { opportunities and constraints for eco-home design }\end{array}$ \\
\hline
\end{tabular}

and building size relative to the number of occupants. The Living Building Challenge, the most stringent guideline in North America, additionally includes categories of social equity and beauty to argue that green buildings not only perform well ecologically, but also socially with enduring esthetics (International Living Future Institute, n.d.). The study of green buildings can also include economic analyses since various building features add costs, save costs, and sometimes pay for themselves over time. The concept of lifecycle analysis is especially pertinent for studying building materials, where the Braungart, McDonough, and Bollinger (2007) notion of "cradle to cradle" products (products designed to avoid the landfill) can be taught. The rating system dedicated specifically to schools in the USA, the Collaborative for High Performing Schools (CHPS), additionally includes the category "operations and metrics," which addresses themes such as green cleaning, ongoing maintenance, and the monitoring of building performance of the building over time (CHPS, 2014). The category of "local and healthy food" is included because green building and landscape design can offer infrastructure for sustainable food production and consumption. This category may be especially pertinent for $\mathrm{K}-12$ educators who already introduce lesson plans on 
local food systems and wish to intersect these themes with built environment education. Finally, the category of "policy" was added to the framework based on focus group feedback that stressed the importance of the political context for green building design. Addressing the broader social systems within which green buildings are created is yet another lens for understanding human impacts on ecosystems.

\section{Conceptual green building knowledge}

Taken together, the categories in Table 2 outline the foundation for an increasingly sophisticated understanding of green buildings. Beyond a grasp of individual building elements (factual knowledge) is the understanding of the complex interrelationships between building elements, and the ways in which these built features interact with the local communities and local ecologies-the human, air, water, plant, and animal life that are affected by the building (conceptual knowledge) (Fig. 1). Conceptual knowledge may include, for example, making the connection between a light bulb, functional illumination in the room, and the building energy that comes from a nearby coal power plant, which is then connected to air quality. Another example of conceptual understanding would be making the connection between an exotic hardwood and the cultural and ecological effects of deforestation in another country, a lesson that would highlight themes of building materiality, biodiversity loss, and social equity. Thus, while factual information within the categories described above can be taught and tested, a more advanced curriculum is needed to help students to connect factual knowledge into a systems-level understanding of green building themes.

\section{Procedural green building knowledge (skills)}

Beyond increasing factual and conceptual knowledge of green buildings, increasing procedural knowledge of green building issues moves students from understanding into action. Procedural knowledge relative to green

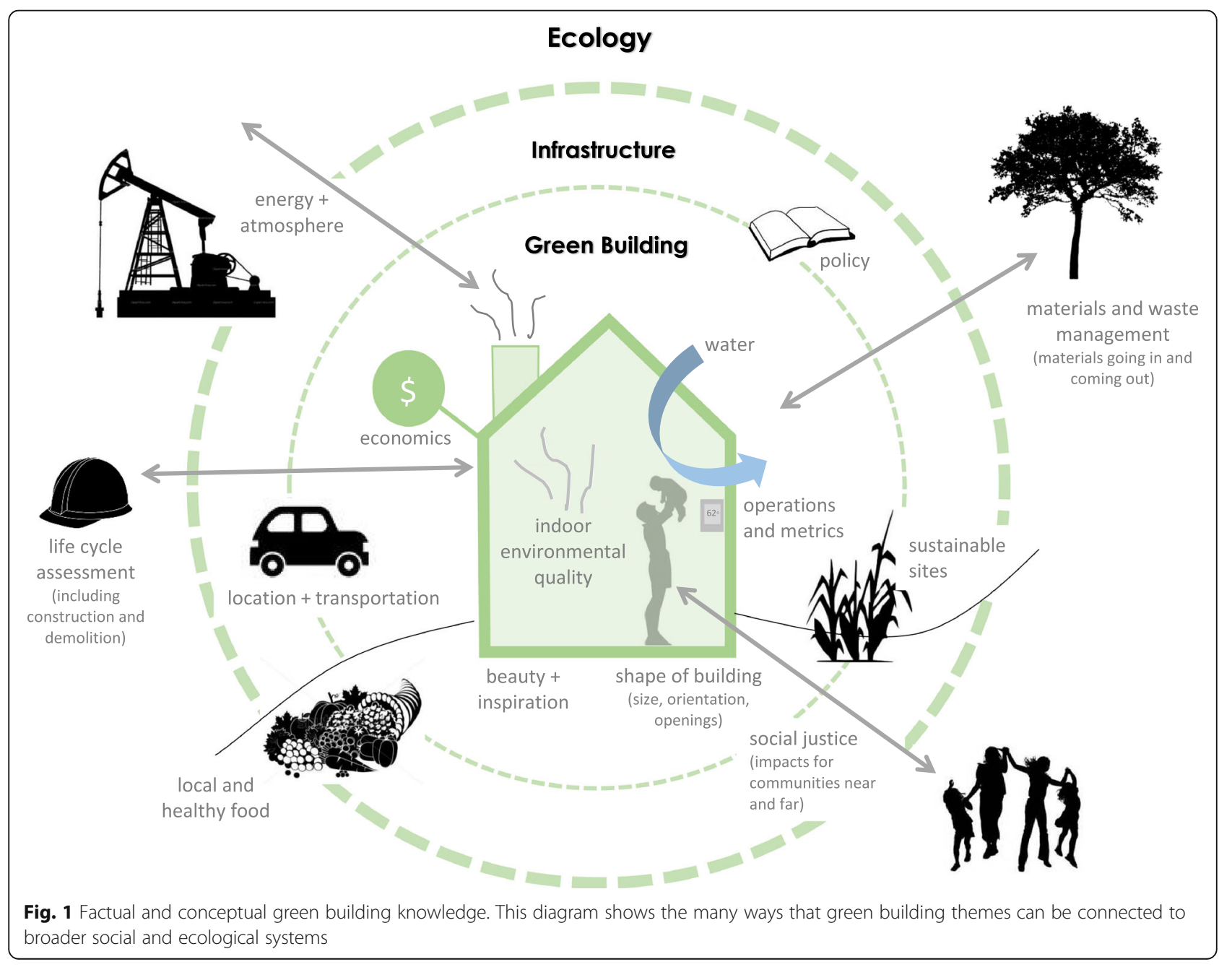


buildings involves an expansive array of skill sets. Table 2 offers examples of procedural green building knowledge for each factual knowledge domain. Procedural knowledge in green buildings can draw on various disciplines. It can involve research on building materials, mathematical calculations on energy or financial savings, or hands-on activities such as building furniture from salvaged materials or installing a rain barrel. Procedural knowledge also spans across the life of a built environment-from designing and constructing to inhabiting and maintaining.

\section{Green building knowledge and the NGSS}

Factual, conceptual, and procedural green building knowledge can be acquired in standards-aligned green building education programs. An in-depth examination of the Next Generation Science Standards (NGSS) reveals the many ways that green building design themes can help educators to meet a variety of performance expectations (PEs) within standards across grade levels (NGSS Lead States, 2013). Additional file 1 illustrates a provisional overlapping of the NGSS standards and PEs with the 14 domains of green building knowledge (from Table 2). While isolated opportunities exist across the NGSS framework in areas such as energy, matter, and Earth's systems, the areas with the highest potential are (1) Earth and Human Activity (ESS3) and (2) Engineering Design (ETS1).

Green building education can align quite well with the Earth and Human Activity (ESS3) PEs from Kindergarten through 12th grade. Beginning in Kindergarten with standards that require students to "communicate solutions that will reduce the impact of humans on the land, water, air, and/or other living things in the local environment" (K-ESS3-3) to standards such as the fifth grade PE to "obtain and combine information about ways individual communities use science ideas to protect the Earth's resources and environment" (5-ESS3-1). Green building themes can advance through the upper grades with middle school requirements such as "apply scientific principles to design a method for monitoring and minimizing a human impact on the environment" (MS-ESS3-3) and high school PEs such as "use a computational representation to illustrate the relationships among Earth systems and how those relationships are being modified due to human activity" (HS-ESS3-6).

The engineering design standards (ETS1) within the NGSS additionally present a clear opportunity for green building education. The PEs for these standards were written quite broadly around the idea of "design process," which can connect to a variety of disciplines such as architecture, engineering, product design, and well beyond. The PEs in ETS1 additionally require rich overlaps between technical, social, and environmental domains such as the middle school Standard MS-ETS1-1:

Define the criteria and constraints of a design problem with sufficient precision to ensure a successful solution, taking into account relevant scientific principles and potential impacts on people and the natural environment that may limit possible solutions (MS-ETS1-1).

The ETS1 standards in high school provide similar, and more complex, guidance:

Evaluate a solution to a complex real-world problem based on prioritized criteria and tradeoffs that account for a range of constraints, including cost, safety, reliability, and aesthetics, as well as possible social, cultural and environmental impacts (HS-ETS1-3).

Standards such as these could engage students, for example, in the design process for a piece of furniture for their classroom that meets a set of given functional, social, and environmental criteria. Beyond encouraging technical skills, these projects additionally provide avenues to make connections to themes of esthetics and social justice. In route, students could engage with additional NGSS standards such as MS-PS1-3 that encourages exploration of how "synthetic materials come from natural resources and impact society" and MS-LS2-3 which requires students to "develop a model to describe the cycling of matter and flow of energy among living and non-living parts of an ecosystem." This is an example of how a single green building theme like furniture design can overlap with the physical and life sciences as students engage in a design process guided by the ETS1 engineering design standards.

\section{Affective dispositions and green buildings}

Just as the "environmentally literate individual has a well-developed set of environmental values or morals" (McBride et al., 2013, p.7), so too does the green building literate citizen. Beyond having knowledge, a green building literate student may also have attitudes and values that shape knowledge and become a basis for environmental action. Within the Table 1 framework, affective dispositions include a person's environmental sensitivity, environmental concern, self-efficacy, feelings of personal responsibility, and willingness to take action. Affective depositions such as these have a dual role as both an outcome to which we might aspire (e.g., environmentally sensitive citizens) and a predictor of other positive outcomes (e.g., environmentally responsible behaviors). Scholars across disciplines have taken an interest in affect for its potential importance in the process 
of learning (e.g., Picard et al., 2004) and for the links to pro-environmental action (e.g., Ajzen, 1991; Hines, Hungerford, \& Tomera, 1987; Stern, 2000). It should be noted, however, that environmentally responsible behaviors are often multi-determined by an array of predictors where attitudes have been shown to be an unstable predictor across studies (Kollmuss \& Agyeman, 2002). Within the Hungerford and Volk (1990) "Environmental Behavior Model," affective dispositions occupy every dimension of the framework-from entry-level to ownership to empowerment variables-that all lead toward citizenship behavior. This is all to say, the relationship between affect and behavior is complex and rarely linear. Research further shows that attitudinal factors, such as environmental sensitivity, are outcomes that typically occur for individuals over many years and are influenced by factors such as role models and time in nature (Chawla, 1998; Marcinkowski, 1998; Tanner, 1980).

Despite the growing body of research on affect in fields of education, environmental education, and conservation psychology, the study of affect in green buildings is yet in the nascent stages. In the realm of green building literature, we have much yet to understand about how affect is influenced by green building design, and conversely, how green building design practices are advanced by people with positive affective dispositions. Each of these angles-alternatively viewing affective dispositions resulting from and contributing to green building practices-merits further elaboration.

First, previous research illustrates that context matters for fostering environmental sensitivity. Chawla (1998) found numerous pathways to environmental careers that included influences such as frequent contact in nature and solitude in nature, both experiences that can be fostered by green landscape design. On the other hand, and more specific to building interiors, McCunn and Gifford (2012) conducted one of the earliest studies on how a green office environment impacts employee environmental attitudes. Their results were surprising in that employee attitudes dropped as green building features increased. The researchers suggest that dissatisfaction with the building design, and perhaps faded novelty of the green building, were potential reasons for the negative attitudes. It appears to make a difference who occupies the green office building, however. A study in Australia found that office building occupants with higher levels of environmental concern were more likely to forgive a green building's shortcomings (Deuble \& de Dear, 2012).

Second, it is possible that positive emotions about green buildings will bring about positive outcomes for green buildings, where positive affect becomes a building block toward action. Sung et al. (2014) present pioneering quantitative work on GBL in a study of over 1000
Taiwanese college students. They found that attitudes about green buildings were an essential link between knowledge and behaviors. In fact, they found that "[w]ithout attitudes and responsibility as mediators, greater knowledge indicated poorer behavior" (Sung et al., 2014, p. 173). Taken together, the research thus far suggests that green building attitudes can work for and against the pursuit of building green. The study of affect and green buildings is complex and potentially fertile area for future research. Research is especially lacking for youth in the K-12 school environment.

Despite the need for better understanding about affect in and for green buildings, there are several key takeaways regarding "affect" for practitioners interested in increasing GBL. The first is that attitudes and values about green buildings are not likely to change rapidly for building users. Green buildings are one potentially positive force for engendering environmental sensitivity along with other factors like access to nature and environmental role models, and these are influences that work over time. Further, practitioners designing curricula and interventions for green building education may want to understand the initial affective dispositions of learners relative to environmental themes to create the appropriate starting point for lesson planning. Finally, affect plays a role in the process of green building education just as it does in any educational process. Fredrickson (2001) argued that positive emotions allow people to "broaden" their scope of attention and "build" intellectual resources. Therefore, green building education that is infused with positive learning experiences may help learners to open up to novel experiences and revise their mental models of what the built environment can be.

\section{Behaviors and green buildings}

The ultimate goal of environmental education is to bring about change not only in people's minds but in tangible benefits to our natural and built environment (e.g., Hines et al., 1987). The work here aligns well with the Sung et al. (2014) view of green building actions that focuses first on involvement and decision-making relative to green design and then expands to encompass more general environmentally responsible actions. Thus, within a framework of GBL, two distinct types of behaviors can be examined: actions that (1) advocate for green building practices, and (2) occur in and around green buildings.

First, a major goal of green building education is to inspire action that advances the green building movement. Marcinkowski (2010) conceptualizes behavior as multi-faceted, including actions taken individually and collectively on levels local, national, and global. These many forms of action are applicable to the topic of GBL. For example, consider the many ways a student could 
take action on energy issues. At the level of the building, a student can help turn off lights and shut down computers. The same student could work with peers in an environmental club to advocate for energy efficiency on their school campus. Further reach beyond the school building might include trying behaviors at home or writing local legislators about energy issues in public buildings. In this way, green building education can provide a link to planning and policy conversations in the classroom given the broader social systems (such as building codes, regulations, and guidelines) that either hinder or support innovative building design.

Second, consider the occupant actions within buildings that impact the performance of a green building. The repertoire of actions possible within a green building are largely determined by the opportunities a building affords such as recycling, composting, adjusting thermostats, and so on. Schools promoting green building education can align opportunities for environmentally friendly practices within the building with educational programming. The lessons for students are twofold. First, students can build awareness about how the physical built environment is structured to either hinder or support environmental action. Second, students can learn how informed and active building occupants can make a difference for their own school building's environmental performance.

\section{Focus group results and discussion}

Education and built environment (BE) professionals provided input on the frameworks in Tables 1 and 2. These tables were improved and Additional file 1 was created as a result of participant feedback. The three broad themes addressed by experts (each given a pseudonym) are summarized below.

\section{Theme 1: framing green building literacy}

The Table 1 framework for GBL resonated across groups and participants. Various professionals, however, recommended different ways to frame the importance of GBL. Numerous experts wanted to see more clear links between green building design and the realm of policy and planning given that the political and city planning context is a critical set of factors that can limit or give rise to innovative green building design (e.g., Simons, Choi, \& Simons, 2009). BE professionals further expressed concern that building occupant political views will shape how individuals experience green buildings and respond to green building education programs, a notion that has some potential connection to the broader discourse on political consumerism (e.g., Wirt, 2017). The theme of policy was thus added to the framework. Claire discussed the complexity by noting that "there's kind of a transactional thing that happens there with the attitudes that people bring into the building" that can either promote or deter environmentally friendly actions in buildings. The Table 1 "affective dimensions" category was split into two sub-themes as a result of this discussion. Stephen, an expert in using green schools as teaching tools, further advocated for stronger ways to frame green buildings for educators. He recommended framing green buildings as physical manifestations and microcosms of the larger environmental values that many educators already seek to foster in students. In sum, conversations across groups revealed the variety of lenses through which green buildings can be viewed. The work here examines green buildings for STEM education and maintains a dominant focus on the building itself and immediate landscape (the set of decisions that are largely within the power of school districts and architectural designers to make). However, educators, curriculum developers, and designers have vast options to tailor green building themes to their unique educational contexts and purposes.

\section{Theme 2: green building knowledge categories}

Numerous focus group participants indicated that Table 2 with "green building knowledge categories" was one of the key contributions of this body of work. As James, a public school curriculum coordinator, expressed:

Table two jumps out as a very effective set of principles and illustrations that dovetails very well into the sort of work that public schools are looking towards when it comes to the meaningful integration of sustainability practices. It's one thing to build the building, but ... the practices are everything (James).

Discussion around the specific Table 2 categories comprised the major portion of both focus group sessions. The green building knowledge categories were thus impacted and refined as a result of the focus group feedback. Participants recommended that the titles of the knowledge categories maintain alignment with the prominent standards for green building design, which may be especially helpful for curriculum within schools with certified green buildings. Key points of conversation (in order of appearance in the framework) included:

- Location and transportation: This category was originally included within "sustainable sites" but was extracted and given its own category as recommended by members of the BE focus group. This choice also reflects the latest changes within the LEED $^{\circ}$ Green Building Rating System (USGBC, n.d.). 
- Social justice: Educator focus group participants debated the inclusion of the "social justice" category. Stephen questioned if the theme deviated to far from the core topic of green buildings and Janice additionally commented that the theme could be difficult to address in lower elementary classes. However, three other participants vigorously defended the importance of keeping social justice in the framework, with one educator noting that "It is so front and center" (Sara) for the work that she does in public schools. James further emphasized the point commenting that "one cannot separate equity from environmental and sustainability focuses. It's essential for kids." These latter perspectives synchronize with the choice of the developers of the rigorous "Living Building Challenge" standards for ecologically friendly buildings, which include social justice as a core set of guidelines for living buildings (International Living Future Institute, n.d.).

- Local and healthy food: The Collaborative for High Performing Schools (CHPS) includes "school gardens" as a credit within the sites category (CHPS, 2014). Given that food system themes largely occur outside the building, the researcher asked participants if this category cohered with the other content in Table 2. Educators and BE professionals overwhelmingly agreed that the built environment plays an important supporting role in sustainable farm-to-table food production and that this category fits well with current health food initiatives already happening at many schools. James summarized the group sentiments:

It [local and healthy food] is an authentic daily practice-driven integration that capitalizes upon required and normal school function, a critical one inside our schools, but we have found that integrating our outdoor garden as well as our hydroponic garden alongside recycling, composting and food donation has been an extraordinarily effective vehicle for all age levels. So I'm glad to see that represented here. "I think it's low hanging fruit that you are wise to include" (James).

Two members of the Educator focus group did express some concern that "there is going to be a lot of red tape" (Janice) and logistical issues (Sara) in terms of connecting school gardens to school cafeterias. Public health concerns, student allergies, and pre-existing contracts with food vendors were several of the potential issues highlighted.

- Policy: As mentioned previously, the topic of politics and policy was noted by BE focus group members as a potentially important issue to include. Inclusion of this category could encourage educators to engage social studies or civics themes into green building lesson planning. This theme could also inspire teaching about the green building rating systems themselves as guidelines that could be adopted into policy in the future.

\section{Theme 3: implementation within schools}

A central theme in the Educator focus group was the ways in which frameworks for GBL can be useful to educators and curriculum developers. The conversation began with James noting his frustration with identifying useful frameworks to inform practice. His comments highlighted the challenge of providing frameworks as tools for curriculum development, and particularly the challenge of striking a balance between providing overly broad versus excessively specific guidance. Janice suggested, and the educators all agreed, that alignment between GBL and science standards is a critical missing piece for promoting adoption of green building education in K-12 classrooms. Additional file 1 was created in response to this concern, and the tables therein reveal a multitude of connections between green building themes and the NGSS standards.

Numerous professionals asked clarifying questions about what types of school buildings, and school systems broadly, are the target audience for GBL frameworks. Within this conversation, the group discussed the ways that GBL can be promoted in schools both with and without green buildings-and for a spectrum of green buildings from partial renovations to entire new construction buildings. Educators additionally emphasized the importance of ensuring that these themes are not only pursued within special private and charter schools, but also within public school systems that may have less access to resources for green building design. The frameworks presented here are broad enough to apply to both green certified and non-green buildings across both school types and age groups. They are tools for educators and curriculum developers to use as a catalyst for connecting their unique contexts to green building design to advance a great variety of learning outcomes in $\mathrm{K}-12$ science classrooms.

Overall, the group of professionals confirmed and expanded the conceptualizations of green building knowledge, contributing to the overarching question guiding this inquiry, which sought to define key qualities of a green building literate citizen. Despite having a variety of professional perspectives among participants, a key limitation to the focus groups was the sampling frame that began with the author's own network and expanded outward. Three participants were foreign born; however, the dominant 
perspectives are US-centric and may need adaptation to other settings.

\section{Conclusion}

Green building education, while prominent in architectural and engineering professions, is scarce for the general public. Green building education can begin in K-12 schooling to enhance science education amid increasing calls to teach students about human impacts on nature (NGSS Lead States, 2013). If advances are to be made for public green building education, a framework for outlining the diverse educational content and outcomes could provide a useful starting point for curricula that are formal, informal, or even non-formal in nature. The "Major features of green building literacy" matrix builds on previous work to propose a framework for green building literacy. The major features discussed were knowledge (factual, conceptual, and procedural), affect, and behavior. This work calls for green building education that is not only factual in nature but also interweaves complex topics into a more conceptual understanding of green buildings and scaffolds toward skills and actions. However, a "strong conception" (Stables \& Bishop, 2001) of green building literacy calls for building occupants who are both "reading" and "writing" green buildings. Building occupants are not only passive dwellers of buildings, but individuals who are an active part of a green building's performance and have the capability to advocate for better building practices.

\section{Additional file}

Additional file 1: Provisional Alignments between the NGSS and Green Building Knowledge Categories. (DOCX 38 kb)

\section{Abbreviations}

BE: Built environment; CHPS: The Collaborative for High Performing Schools; GBL: Green building literacy; IEQ: Indoor environmental quality; LEED: Leadership in Energy and Environmental Design; NGSS: Next Generation Science Standards; PE: Performance expectation; USGBC: United States Green Building Council

\section{Acknowledgements \\ The author would like to thank the panel of experts for their time and insight in the development of the frameworks presented in this study. The author would additionally like to thank Dr. Michaela Zint and Dr. Laura Zangori for their assistance with early drafts of this work. Additional gratitude is extended to the peer reviewers whose constructive feedback contributed greatly to this piece.}

\section{Funding}

This open-access publication is supported by the National Institute of Food and Agriculture federal agricultural experiment station capacity grants (project no. MO-HANC0001) from the United States Department of Agriculture.

\section{Availability of data and materials}

The datasets used and/or analyzed during the current study are available from the corresponding author on reasonable request.

\section{Authors' contributions}

The author made $100 \%$ of the contributions to the current work. The author read and approved the final manuscript.

\section{Authors' information}

Dr. Laura Cole is an interior design educator and architectural studies scholar who has been involved in the green building movement in various capacities for over 15 years. She worked as a designer in the global architecture firm of Perkins + Will where she co-lead the sustainability team and mentored junior designers on their pathways toward becoming LEED accredited professionals. Her Ph.D. work was in the combined areas of Architecture and Natural Resources and Environment. She is now an educator at the University of Missouri where she teaches sustainable design and works on interdisciplinary research teams to advance green building education in theory and practice.

\section{Competing interests}

The author declares that she has no competing interests.

\section{Publisher's Note}

Springer Nature remains neutral with regard to jurisdictional claims in published maps and institutional affiliations.

Received: 7 September 2018 Accepted: 22 April 2019

Published online: 29 May 2019

\section{References}

Ajzen, I. (1991). The theory of planned behavior. Organizational Behavior and Human Decision Processes, 50(2), 179-211. https://doi.org/10.1016/07495978(91)90020-T.

Barr, S., Dunbar, B., \& Schiller, C. (2012). Sustainability in schools: Why green buildings have become a catalyst. Educational Facility Planner, 46(1), 19-22.

Berkowitz, A. R., Ford, M. E., \& Brewer, C. A. (2005). A framework for integrating ecological literacy, civics literacy, and environmental citizenship in environmental education. In E. Johnson \& M. Mappin (Eds.), Environmental education and advocacy: Changing perspectives of ecology and education (pp. 227-266). Cambridge: Cambridge University Press. https://doi.org/10.2980/ 1195-6860(2006)13[423:eeaacp]2.0.co;2.

Bloom, B. S., Engelhart, M. D., Furst, E. J., Hill, W. H., \& Krathwohl, D. R. (1956). Taxonomy of educational objectives: The classification of educational goals. Handbook 1: Cognitive domain. New York: David McKay.

Braungart, M., McDonough, W., \& Bollinger, A. (2007). Cradle-to-cradle design: Creating healthy emissions - a strategy for eco-effective product and system design. Journal of Cleaner Production, 15(13), 1337-1348. https://doi.org/10. 1016/j.jclepro.2006.08.003.

Chawla, L. (1998). Significant life experiences revisited: A review of research on sources of environmental sensitivity. The Journal of Environmental Education, 29(3), 11-21. https://doi.org/10.1080/00958969809599114.

CHPS (2014). Project scorecard: 2014 U.S. collaborative for high performing school (CHPS) criteria. https://chps.net/sites/default/files/2014_US-CHPSScorecard.pdf. Accessed 1 Feb 2019.

Cole, L. B. (2013). The green building as medium for environmental education. The Michigan Journal of Sustainability, 1(1), 161-169. https://doi.org/10.3998/ mjs.12333712.0001.012.

Cole, L. B. (2015). Fostering green building literacy in the school building: A study of five middle schools in the United States. Children \& Youth Environments, 25(3), 145-174. https://doi.org/10.7721/chilyoutenvi.25.3.0145.

Cole, L. B. (2018). The teaching green building: Five theoretical perspectives. In F. W. Leal, R. Marans, \& J. Callewaert (Eds.), Handbook of sustainability and social science research. World sustainability series (pp. 107-125). Cham: Springer. https://doi.org/10.1007/978-3-319-67122-2_6.

Cole, L. B., McPhearson, T., Herzog, C., \& Kudryavtsev, A. (2017). Green infrastructure. In A. Russ \& M. E. Krasny (Eds.), Urban environmental education review (pp. 261-270). Ithaca: Cornell Press.

de Saussure, F. (1966). Course in general linguistics. New York: McGraw Hill.

DeBoer, G. E. (2000). Scientific literacy: Another look at its historical and contemporary meanings and its relationship to science education reform. Journal of Research in Science Teaching, 37(6), 582-601. https://doi.org/10. 1002/1098-2736(200008)37:6<582::AID-TEA5>3.0.CO;2-L.

Deuble, M. P., \& de Dear, R. J. (2012). Green occupants for green buildings: The missing link? Building and Environment, 56, 21-27. https://doi.org/10.1016/j. buildenv.2012.02.029. 
Fredrickson, B. L. (2001). The role of positive emotions in positive psychology: The broaden-and-build theory of positive emotions. American Psychologist, 56(3), 218. https://doi.org/10.1037/0003-066X.56.3.218.

Gill, Z. M., Tierney, M. J., Pegg, I. M., \& Allan, N. (2010). Low-energy dwellings: The contribution of behaviours to actual performance. Building Research \& Information, 38(5), 491-508. https://doi.org/10.1080/09613218.2010.505371.

Higgs, A. L., \& McMillan, V. M. (2006). Teaching through modeling: Four schools' experiences in sustainability education. The Journal of Environmental Education, 38(1), 39-53. https://doi.org/10.3200/joee.38.1.39-53.

Hines, J., Hungerford, H., \& Tomera, A. (1987). Analysis and synthesis of research on responsible environmental behavior: A meta-analysis. Journal of Environmental Education, 18(2), 1-8. https://doi.org/10.1080/00958964.1987.9943482.

Hungerford, H. R., \& Volk, T. L. (1990). Changing learner behavior through environmental education. The Journal of Environmental Education, 21(3), 8-21. https://doi.org/10.1080/00958964.1990.10753743.

International Living Future Institute. (n.d.). The living building challenge 3.1: A visionary path to a regenerative future. http://living-future.org/lbc. Accessed 1 Feb 2019.

lozzi, L., Laveault, D., \& Marcinkowski, T. (1990). Assessment of learning outcomes in environmental education. In Methods and techniques for evaluating environmental education. Paris: UNESCO.

Jan, Y.-L., Lin, M.-L., Shiao, K.-Y., Wei, C.-C., Huang, L.-T., \& Sung, Q.-C. (2012). Development of an evaluation instrument for green building literacy among college students in Taiwan. International Journal of Technology and Human Interaction, 8(3), 31-45. https://doi.org/10.4018/jthi.2012070104.

Kollmuss, A., \& Agyeman, J. (2002). Mind the gap: Why do people act environmentally and what are the barriers to pro-environmental behavior? Environmental Education Research, 8(3), 239-260. https://doi.org/10.1080/ 13504620220145401.

Krathwohl, D. R. (2002). A revision of Bloom's taxonomy: An overview. Theory Into Practice, 41(4), 212-218. https://doi.org/10.1207/s15430421tip4104_2.

Marcinkowski, T. (1998). Predictors of responsible environmental behavior: A review of three dissertation studies. In H. R. Hungerford, W. Bluhm, T. Volk, \& J. Ramsey (Eds.), Essential readings in environmental education (pp. 247-276). Champaign: Stipes.

Marcinkowski, T. (2010). Major features of environmental literacy. Melbourne: Department of Science and Mathematics Education, Florida Institute of Technology.

McBride, B., Brewer, C., Berkowitz, A., \& Borrie, W. (2013). Environmental literacy, ecological literacy, ecoliteracy: What do we mean and how did we get here? Ecosphere, 4(5), 1-20. https://doi.org/10.1890/ES13-00075.1.

McCunn, L. J., \& Gifford, R. (2012). Do green offices affect employee engagement and environmental attitudes? Architectural Science Review, 55(2), 128-134. https://doi.org/10.1080/00038628.2012.667939.

McLennan, J. F. (2004). The philosophy of sustainable design: The future of architecture. Kansas City: Ecotone Publishing.

Monroe, M. C., Andrews, E., \& Biedenweg, K. (2008). A framework for environmental education strategies. Applied Environmental Education \& Communication, 6(3-4), 205-216. https://doi.org/10.1080/ 15330150801944416.

Murry, J. W., Jr., \& Hammons, J. O. (1995). Delphi: A versatile methodology for conducting qualitative research. The Review of Higher Education, 18(4), 423436. https://doi.org/10.1353/rhe.1995.0008.

NGSS Lead States. (2013). Next generation science standards: For states, by states. Washington, D.C.: National Academies Press.

Pastorius, E., \& Marcinkowski, T. (2013). A comparative analysis of federal and selected state green school frameworks. In Paper presented at the green schools national conference, west Palm Beach, Florida.

Picard, R. W., Papert, S., Bender, W., Blumberg, B., Breazeal, C., Cavallo, D., et al. (2004). Affective learning-A manifesto. BT Technology Journal, 22(4), 253269. https://doi.org/10.1023/B:BTTJ.0000047603.37042.33.

Portillo, M., \& Rey-Barreau, J. A. (1995). The place of interior design in K-12 dducation and the built environment education movement. Journal of Interior Design, 21(1), 39-43. https://doi.org/10.1111/j.1939-1668.1995. tb00207.x.

Roberts, D. (2007). Scientific literacy/science literacy. In S. K. Abell \& N. G. Lederman (Eds.), Handbook of research on science education (pp. 729-780). Mahwah: Lawrence Erlbaum Associates.

Roth, C. E. (1992). Environmental literacy: Its roots, evolution and directions in the 1990s. Columbus: ERIC Clearinghouse for Science, Mathematics, and Environmental Education.
SEED Center. (n.d.). Defining the Green Workforce. http://theseedcenter.org/ Resources/SEED-Toolkits/Defining-the-Green-Workforce. Accessed 1 Sept 2018.

Shapiro, B. (2015). Structures that teach: Using a semiotic framework to study the environmental messages of learning settings. Eco-thinking, 1(1), 5-17.

Shiao, K. Y., Lin, M. L., \& Sung, Q. C. (2013). Curriculum innovation for fostering green building literacy in general education. Applied Mechanics and Materials, 284-287, 1290-1294. https://doi.org/10.4028/www.scientific.net/amm.284-287.1290.

Simons, R., Choi, E., \& Simons, D. (2009). The effect of state and city green policies on the market penetration of green commercial buildings. Journal of Sustainable Real Estate, 1(1), 139-166.

Sobel, D. (2004). Place-based education: Connecting classroom and community. Nature and Listening, 4, 1-7.

Stables, A. (1998). Environmental literacy: Functional, cultural, critical. The case of the SCAA guidelines. Environmental Education Research, 4(2), 155-164. https:// doi.org/10.1080/1350462980040203.

Stables, A., \& Bishop, K. (2001). Weak and strong conceptions of environmental literacy: Implications for environmental education. Environmental Education Research, 7(1), 89-97. https://doi.org/10.1080/13504620125643.

Stern, P. C. (2000). Toward a coherent theory of environmentally significant behavior. Journal of Social Issues, 56, 407-424. https://doi.org/10.1111/0022 4537.00175.

Sung, Q.-C., Lin, M.-L., Shiao, K.-Y., Wei, C.-C., Jan, Y.-L., \& Huang, L.-T. (2014). Changing behaviors: Does knowledge matter? A structural equation modeling study on green building literacy of undergraduates in Taiwan. Sustainable Environment Research, 24(3), 173-183.

Tanner, R. T. (1980). Significant life experiences: A new research area in environmental education. The Journal of Environmental Education, 11(4), 20 24. https://doi.org/10.1080/00958964.1980.9941386.

Tawain Green Building Label. (n.d.). About Green Building Labeling. http:// twgbqanda.com/english/e_about.php?Type=1\&menu=e_about_class\&pic_ dir_list=0\#. Accessed 1 Feb 2019.

U.S. Energy Information Administration. (2012). Annual energy outlook 2012: With projections to 2035. Washington, DC: Government Printing Office.

U.S. Environmental Protection Agency. (n.d.). Water Use Today. https://www3.epa. gov/watersense/our_water/water_use_today.html. Accessed 1 Feb 2019.

USGBC. (2008). LEED 2009 for Schools New Construction and Major Renovations. http://www.usgbc.org/ShowFile.aspx?DocumentID=5547. Accessed 1 Feb 2019.

USGBC. (n.d.). United States Green Building Council. http://www.usgbc.org/. Accessed 1 Feb 2019.

Wirt, F. M. (2017). Politics, products, and markets: Exploring political consumerism past and present. New York: Routledge.

Wu, D. W. L., DiGiacomo, A., Lenkic, P. J., Wong, V. K., \& Kingstone, A. (2016). Being in a "green" building elicits "greener" recycling, but not necessarily "better" recycling. PLoS One, 11(1), e0145737. https://doi.org/10.1371/journal.pone.0145737.

\section{Submit your manuscript to a SpringerOpen ${ }^{\circ}$ journal and benefit from:}

- Convenient online submission

- Rigorous peer review

- Open access: articles freely available online

High visibility within the field

- Retaining the copyright to your article

Submit your next manuscript at $>$ springeropen.com 